\title{
Steady heat transfer by natural (free) convection and radiation, for a horizontal circular pipe surrounded by air, using the Mathcad ${ }^{\circledR}$ software
}

\author{
Transfer constant de căldură prin convecție naturală (liberă) și radiație, \\ pentru o țeavă circulară orizontală înconjurată de aer, folosind software-ul \\ Mathcad ${ }^{\circledR}$
}

\section{Gelu-Adrian CHISĂLIŢĀ ${ }^{1}$, Raluca MOLDOVAN ${ }^{2}$}

\author{
${ }^{1}$ Technical University of Cluj-Napoca, Romania \\ Faculty of Building Services Engineering, Department of Building Services Engineering \\ e-mail: gelu.chisalita@insta.utcluj.ro \\ ${ }^{2}$ Technical University of Cluj-Napoca, Romania \\ Faculty of Building Services Engineering, Department of Building Services Engineering \\ e-mail: raluca.moldovan@insta.utcluj.ro
}

DOI: $10.37789 /$ rjce.2021.12.4.2

\begin{abstract}
The paper presents a study on the heat transfer in steady state, by natural convection and radiation, from a circular pipe to the surrounding air. Using the Mathcad $\mathbb{}$ software application, the calculation procedure for the average heat transfer coefficient on the surface by convection, radiation and combined was implemented on the computer, as well as the determination of the heat flux density (the rate of heat transfer per unit time per unit length) taking into account various values of the outer surface temperature of the pipe. The results of the study show that neglecting the heat transfer by thermal radiation, even for low temperatures with values in the range of $40^{\circ} \mathrm{C} \ldots 90^{\circ} \mathrm{C}$, can lead to relatively high technical errors in estimating the heat loss of pipes. In these situations, is necessary to take into account the combined heat transfer by natural convection and thermal radiation.
\end{abstract}

Keywords: heat, transfer, steady state, natural convection, radiation, Mathcad

Rezumat. Lucrarea prezintă un studiu privind transmiterea căldurii în regim termic staționar, prin convecție termică liberă și radiație, de la o conductă cu secțiune circulară către aerul înconjurător. Cu ajutorul aplicației software Mathcad ${ }^{\circledR}$, a fost implementată pe calculator procedura de calcul pentru coeficienții de transfer termic superficiali prin convecție, radiație și combinat, precum și determinarea valorii fluxului termic unitar raportat la unitatea de lungime transmis mediului ambiant, având $\hat{\imath}$ vedere diverse valori ale temperaturii pe suprafața exterioară a conductei. Rezultatele studiului indică faptul că neglijarea transferului de căldură prin radiație termică, chiar în cazul unor temperaturi având valori cuprinse în intervalul $40^{\circ} \mathrm{C} . . .90^{\circ} \mathrm{C}$, poate conduce la erori tehnice relativ ridicate privind estimarea pierderilor de căldură ale conductelor, fiind necesar a lua în calcul în aceste situații transferul termic combinat prin convecție și radiație.

Cuvinte cheie: transfer, căldură, staționar, convecție termică, liberă, radiație termică, Mathcad 


\section{Introduction}

The general approach of studying and solving a case of thermal convection is usually done by using empirical correlations indicated in the literature, characteristic of a class, category, type etc. of a convection phenomenon analyzed, such as: thermal convection with or without phase change, natural (free) convection or forced convection, thermal convection in open spaces (unlimited spaces or large volumes) or thermal convection in closed spaces (limited spaces or small volumes) etc.

For the case of natural (free) convection that occurs in open spaces, the commonly used empirical correlation has the general form (1) [1], [2], [3], [4] etc.

$$
N u=C \cdot(G r \cdot P r)^{m} \text { or } N u=C \cdot R a^{m}
$$

where:

- $\mathrm{Nu}$ - Nusselt number;

- $\mathrm{Gr}$ - Grashof number;

- Pr - Prandtl number;

- $\mathrm{Ra}-$ Rayleigh number $(\mathrm{Ra}=\mathrm{Gr} \cdot \mathrm{Pr})$;

- $\mathrm{C}, \mathrm{m}$ - Dimensionless constants depending on the fluid flow regime.

The average Nusselt number $(\mathrm{Nu})$ is expressed by the general definition relationship (2) [1], [4,], [5], [6], [7] etc.

where:

$$
N u=\frac{\alpha}{\lambda} \cdot l_{c}
$$

- $\alpha$-Convection heat transfer coefficient $\left[\mathrm{W} / \mathrm{m}^{2} \cdot \mathrm{K}\right]$;

- $\lambda$ - Thermal conductivity of the fluid $[\mathrm{W} / \mathrm{m} \cdot \mathrm{K}]$;

- $1_{\mathrm{c}}-$ Characteristic length [m].

The Grashof number (Gr) can be determined using the formula (3) [1], [4], [5] etc.

where:

$$
G r=\frac{g \cdot l_{c}^{3}}{v^{2}} \cdot \beta \cdot \Delta t
$$

- $\mathrm{g}$ - Acceleration due to gravity $\left[\mathrm{m} / \mathrm{s}^{2}\right]$;

- $1_{\mathrm{c}}$ - Characteristic length $[\mathrm{m}]$;

- $v$ - Kinematic viscosity $\left[\mathrm{m}^{2} / \mathrm{s}\right]$;

- $\beta$ - Isobaric volume expansion coefficient $[1 / \mathrm{K}]$;

- $\Delta \mathrm{t}$ - Temperature difference $\Delta \mathrm{t}=\mathrm{t}_{\mathrm{f}}-\mathrm{t}_{\mathrm{s}}$ (or vice versa) $\left[{ }^{\circ} \mathrm{C}\right]$.

The Prandtl number (Pr) is expressed using the relationship (4) [1], [3], [4], [5], [6] etc.

where:

$$
\operatorname{Pr}=\frac{v}{a}
$$

- $v$ - Kinematic viscosity $\left[\mathrm{m}^{2} / \mathrm{s}\right]$;

- a-Thermal diffusivity (heat diffusivity) $\left[\mathrm{m}^{2} / \mathrm{s}\right]$.

Usually, the Prandtl number is determined from the tables of properties for various fluids, depending on the temperature. 
Steady heat transfer by natural (free) convection and radiation, for a horizontal circular pipe surrounded by air, using the Mathcad® software

Knowing the value of the Nu number, one can calculate from relationship (1) the heat transfer coefficient by convection $\alpha_{C}$, using the formula (5) [1], [4], [5], [7] etc.

$$
\alpha_{C}=\frac{N u \cdot \lambda}{l_{c}}
$$

and then, from Newton's law (6) is obtained the rate of heat transfer by natural convection (heat flux) $\dot{Q}$ [1], [2], [3], [4], [5], [6] etc.

$$
\dot{Q}=\alpha_{C} \cdot A \cdot\left(t_{f}-t_{s}\right)[\mathrm{W}]
$$

where:

- $\alpha_{\mathrm{C}}-$ Average heat transfer coefficient by convection $\left[\mathrm{W} / \mathrm{m}^{2} \cdot \mathrm{K}\right]$;

- $t_{\mathrm{f}}-$ Temperature of the fluid $\left[{ }^{\circ} \mathrm{C}\right]$;

- $t_{s}$ - Temperature of the contact surface between solid and fluid $\left[{ }^{\circ} \mathrm{C}\right]$;

- A - Heat transfer surface area $\left[\mathrm{m}^{2}\right]$.

In order to determine the heat flux density $\dot{\mathrm{q}}$ per unit length (the rate of heat transfer per unit time per unit length), in the case of a circular pipe with diameter $d$, we can use the relationship (7) [4], [8], [9] etc.

$$
\dot{q}_{C}=\alpha_{C} \cdot(\pi \cdot d) \cdot\left(t_{f}-t_{s}\right)\left[\frac{\mathrm{w}}{\mathrm{m}}\right]
$$

where the product $(\pi \cdot d)$ represents the lateral heat transfer surface area corresponding to a pipe length $\mathrm{L}=1.0 \mathrm{~m}$.

If heat transfer by thermal radiation is also taken into account, a heat transfer coefficient by radiation $\alpha_{R}$ can be determined, using the general relationship (8) [4], [5], [8], [9] etc.

where:

$$
\alpha_{R}=\frac{\varepsilon_{12} \cdot C_{0} \cdot\left[\left(\frac{T_{1}}{100}\right)^{4}-\left(\frac{T_{2}}{100}\right)^{4}\right]}{T_{1}-T_{2}}\left[\frac{\mathrm{W}}{\mathrm{m}^{2} \cdot \mathrm{K}}\right]
$$

- $\varepsilon_{12}-$ Reciprocal emission-absorption coefficient [-];

- $\mathrm{T}_{1}, \mathrm{~T}_{2}-$ Absolute temperatures of surfaces $[\mathrm{K}]$;

- $\mathrm{C}_{0}$ - The radiation coefficient of the absolute black body, $\mathrm{C}_{0}=5.67 \mathrm{~W} / \mathrm{m}^{2} \cdot \mathrm{K}^{4}$.

The reciprocal emission-absorption coefficient $\varepsilon_{12}$ is calculated with the relationships indicated in the literature, characteristic of a certain case of thermal radiation [2], [3], [4], [5], [6], [8] ş.a.

For example, for the case of two surfaces $S_{1}$ and $S_{2}$, enclosed in each other, one can use the general relationship (9) [4], [5], [8] etc.

$$
\varepsilon_{12}=\frac{1}{\frac{1}{\varepsilon_{1}}+\frac{S_{1}}{S_{2}} \cdot\left(\frac{1}{\varepsilon_{2}}-1\right)}[-]
$$

where $\varepsilon_{1}$ represents the emission-absorption coefficient of surface $S_{1}$ and $\varepsilon_{2}$ is the emission-absorption coefficient of surface $\mathrm{S}_{2}$.

The heat flux density $\dot{\mathrm{q}}_{\mathrm{R}}$ (per unit length), transferred by thermal radiation in the case of a cylindrical body having a diameter $\mathrm{d}$, for example a pipe with a circular section, is calculated by using the formula (10) [4], [5], [8], [9] etc.

$$
\dot{q}_{R}=\varepsilon_{12} \cdot C_{0} \cdot\left[\left(\frac{T_{1}}{100}\right)^{4}-\left(\frac{T_{2}}{100}\right)^{4}\right] \cdot(\pi \cdot d)\left[\frac{\mathrm{w}}{\mathrm{m}}\right]
$$


Considering the simultaneous action of the two fundamental modes of heat transfer: thermal convection and thermal radiation, to determine the heat flux density $\dot{\mathrm{q}}_{\mathrm{CR}}$ (per unit length) transferred by both convection and radiation, a combined heat transfer coefficient by convection and radiation $\alpha_{C R}$ is calculated using the formula (11) [4], [5] etc.

$$
\alpha_{C R}=\alpha_{C}+\alpha_{R}
$$

and then applying the relationship (7), for example in form (12) or (13)

$$
\begin{gathered}
\dot{q}_{C R}=\alpha_{C R} \cdot(\pi \cdot d) \cdot\left(t_{f}-t_{s}\right)\left[\frac{\mathrm{w}}{\mathrm{m}}\right] \\
\dot{q}_{C R}=\frac{t_{f}-t_{s}}{\frac{1}{\pi \cdot d \cdot \alpha_{C R}}}\left[\frac{\mathrm{w}}{\mathrm{m}}\right]
\end{gathered}
$$

As an alternative calculation or as a verification procedure, if the two-heat flux density $\dot{\mathrm{q}}_{C}$ and $\dot{\mathrm{q}}_{\mathrm{R}}$ were previously determined using relationships (7) and (10), the heat flux density $\dot{\mathrm{q}}_{\mathrm{CR}}$ (per unit length), transferred by convection and radiation, is calculated using the formula (14)

$$
\dot{q}_{C R}=\dot{q}_{C}+\dot{q}_{R}\left[\frac{\mathrm{w}}{\mathrm{m}}\right]
$$

This paper presents a study on how to solve a case of combined heat transfer, by natural (free) convection in open spaces and thermal radiation, for a circular pipe with an outside diameter $\mathrm{d}_{\mathrm{e}}$, surrounded by a fluid (air) as in figure 1 .

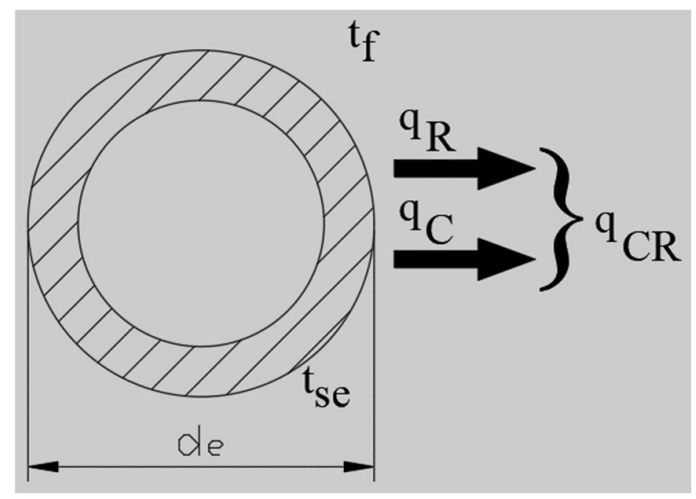

Fig. 1. Circular pipe surrounded by fluid (air)

The implementation of the problem-solving procedure was performed using the

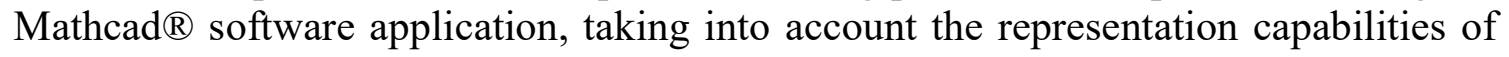
this computer program regarding the following:

$>$ Describing the calculation relationships mentioned above using a language as close as possible with the natural one;

Enhanced possibilities to operate with various measurement units and their combinations;

$>$ Efficient management of the thermophysical properties of the working fluids;

$>$ Creating some general functions, more simple or more complex, used in calculations;

Stylish presentation of the numerical and/or graphical results obtained etc. 
Steady heat transfer by natural (free) convection and radiation, for a horizontal circular pipe surrounded by air,

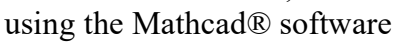

The method of problem-solving presented in this paper is quite easy to implement on computer and has the advantage of quickly obtaining the pursued numerical and/or graphical results.

Also, the indicated method is particularly useful especially in cases where some data of the problem may undergo a series of changes, compared to the initial situation treated in a solving phase. For example, the outer surface temperature of the pipe $t_{\text {se }}$ can vary in a certain technical range of interest, the fluid temperature $t_{f}$ with which the heat exchange occurs may have certain reference values, the pipe geometry is modified or the material from which it is made is changed etc.

\section{Methodology of solving the heat transfer problem}

The technical application proposed for solve in this paper has the initial data and requirements specified by the following statement:

A pipe $\phi 1$ " $(25 \times 2.5 \mathrm{~mm})$, having a length $L=1 \mathrm{~m}$, it is placed horizontally in calm air. Knowing that the outer surface temperature of the pipe is $t_{s e}=50^{\circ} \mathrm{C}$ and the fluid (air) temperature is $t_{f}=10^{\circ} \mathrm{C}$, determine the followings:

a) The heat transfer coefficient by convection from the pipe surface to air;

b) The heat flux transferred by convection from the pipe surface to air;

c) The heat transfer coefficient by radiation;

d) The heat flux transferred by radiation;

e) The heat transfer coefficient by convection and radiation;

f) The heat flux transferred by convection and radiation.

The creation of the automatic spreadsheet used to solve the proposed case involves performing several successive work steps, which will be described below.

\section{DATELE PROBLEMEI}

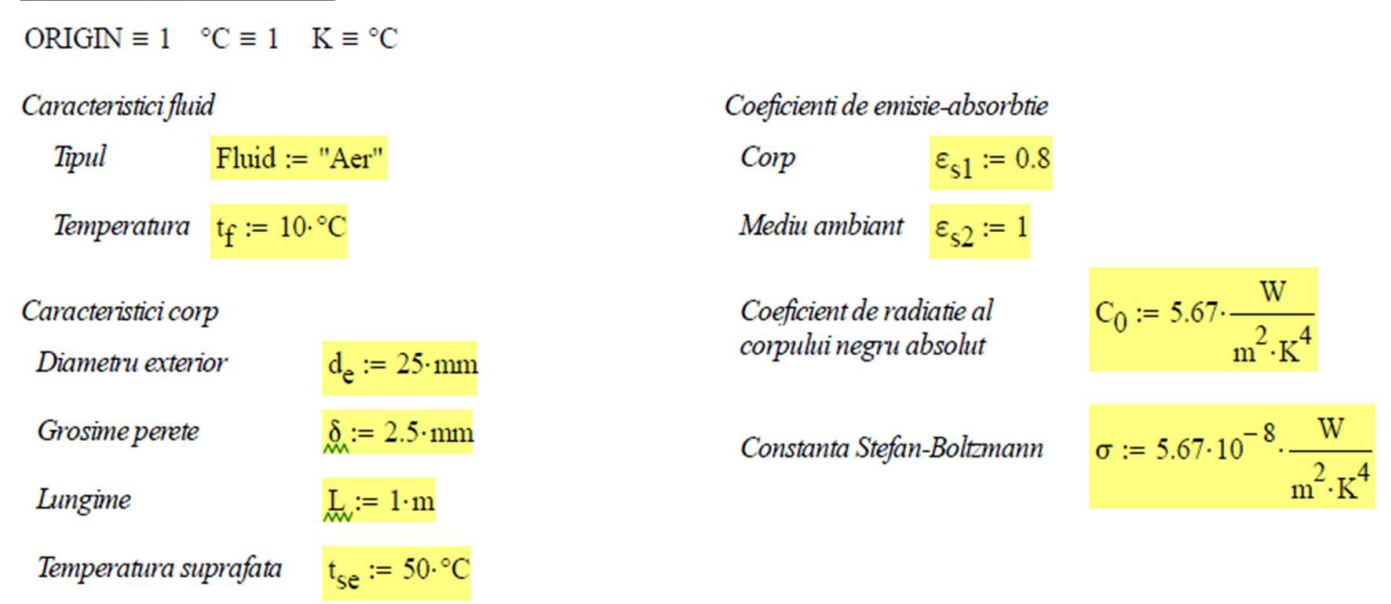

Fig. 2. The implementation of the initial data 
First, the initial data of the problem are specified and implemented. These are represented by: the characteristics of the working fluid, the geometric and thermal characteristics of the pipe, the emission-absorption coefficients of the body and the environment, as well as the values of the radiation coefficient of the absolute black body, respectively the Stefan-Boltzmann constant (figure 2).

Because a series of initial data such as: outer surface temperature of the pipe $t_{\text {se, }}$ fluid temperature $t_{f}$, emission-absorption coefficients, geometry of the pipe etc. may undergo various changes, it is preferable specify them as separate variables instead of using constant values entered directly in calculation formulas.

The function for calculating the heat transfer coefficient by convection $\alpha_{\mathrm{C}}$ shall be introduced in accordance with relationship (5) and the functions used for the determination by linear interpolation of the thermophysical properties of the working fluid (figure 3) shall be introduced using the properties table from figure 4 [8], [9] etc.

$$
\begin{aligned}
& \text { a) Coeficientul de convectie de la corp la fluid } \\
& \text { Criterul Nusselt } \mathrm{Nu}=\frac{\alpha}{\lambda} \cdot 1_{\mathrm{c}} \quad \text { Coeficientul de convectie } \quad \alpha=\mathrm{Nu} \cdot \frac{\lambda}{1_{\mathrm{c}}} \quad \text { fn_ } \alpha\left(\mathrm{Nu}, \lambda, 1_{\mathrm{c}}\right):=\mathrm{Nu} \cdot \frac{\lambda}{1_{\mathrm{c}}} \\
& \text { Functïle proprietatilor fizice } \\
& \text { fn_ } \rho\left(\text { Temp, Densitate, ValTemp) }:=\operatorname{linterp}\left(\text { Temp, Densitate, ValTemp) } \cdot \frac{\mathrm{kg}}{\mathrm{m}^{3}}\right.\right. \\
& \text { fn_ } \lambda\left(\text { Temp, Cond_termica, ValTemp) }:=\operatorname{linterp}(\text { Temp, Cond_termica, ValTemp }) \cdot \frac{\mathrm{W}}{\mathrm{m} \cdot{ }^{\circ} \mathrm{C}}\right. \\
& \text { fn_v(Temp, Visc_cinematica, ValTemp) }:=\operatorname{linterp}(\text { Temp, Visc_cinematica, ValTemp }) \cdot \frac{\mathrm{m}^{2}}{\mathrm{~s}} \\
& \text { fn_Pr(Temp, Prandtl, ValTemp) := linterp(Temp, Prandtl, ValTemp) }
\end{aligned}
$$

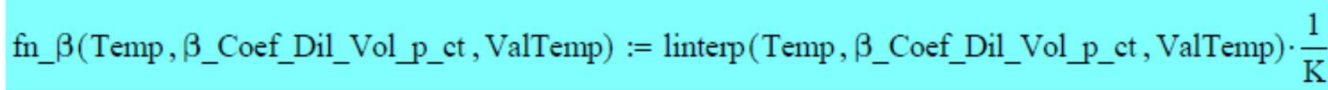

Fig. 3. $\alpha$ function and linear interpolation functions

The mean fluid temperature shall be determined using the usual relationship (15)

$$
t_{m}=\frac{t_{f}+t_{s}}{2}\left[{ }^{\circ} \mathrm{C}\right]
$$

which is implemented by the generic function $\mathrm{fn} \mathrm{t}_{\mathrm{m}}\left(\mathrm{t}_{1}, \mathrm{t}_{2}\right)$ and corresponding to its value the thermophysical properties of the working fluid are calculated: thermal conductivity $\left(\lambda_{\mathrm{f}}\right)$, kinematic viscosity $\left(v_{\mathrm{f}}\right)$ and Prandtl number $\left(\operatorname{Pr}_{\mathrm{f}}\right)$.

The results given in figure 5 were obtained, where the characteristic length $1_{c}$ used in the calculations below is also stated. 
Steady heat transfer by natural (free) convection and radiation, for a horizontal circular pipe surrounded by air,

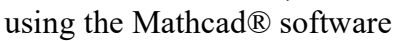

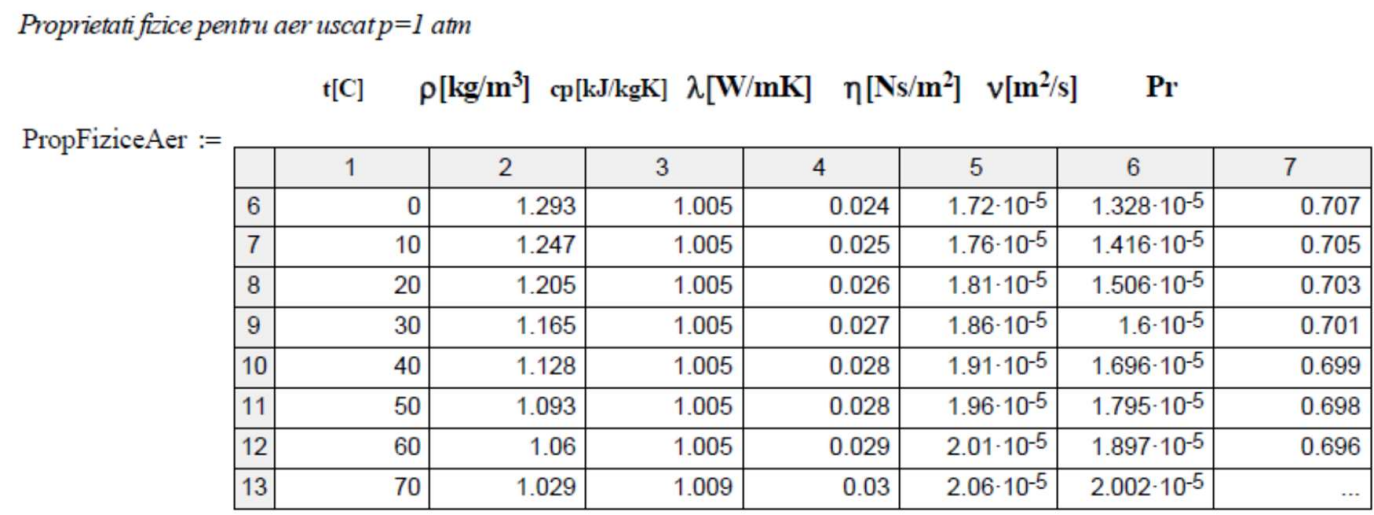

Index_t $:=1$ Index_ $\rho:=2$ Index_c $c_{p}:=3$ Index_ $\lambda:=4$ Index_ $\eta:=5$ Index_ $\nu:=6$ Index_Pr $:=7$

Fig. 4. The thermophysical properties of air [8], [9] etc

$$
\begin{aligned}
& \text { Temperatura medie } \quad \mathrm{t}_{\mathrm{m}}=\frac{\mathrm{t}_{1}+\mathrm{t}_{2}}{2} \quad \mathrm{fn}_{-} \mathrm{t}_{\mathrm{m}}\left(\mathrm{t}_{1}, \mathrm{t}_{2}\right):=\frac{\mathrm{t}_{1}+\mathrm{t}_{2}}{2} \\
& \mathrm{t}_{\mathrm{m}}:=\mathrm{fn}_{-} \mathrm{t}_{\mathrm{m}}\left(\mathrm{t}_{\mathrm{se}}, \mathrm{t}_{\mathrm{f}}\right) \quad \mathrm{t}_{\mathrm{m}}=30 \cdot{ }^{\circ} \mathrm{C} \\
& \text { Proprietatile ficice pentru } \quad \text { Fluid }=\text { "Aer" la temperatura medie } \quad \mathrm{t}_{\mathrm{m}}=30 \cdot{ }^{\circ} \mathrm{C} \\
& \left.\lambda_{\mathrm{f}}:=\mathrm{fn}_{-} \lambda\left(\text { PropFiziceAer }^{\langle\text {Index_t }}{ }^{\rangle}, \text {PropFiziceAer }{ }^{\langle\text {Index }} \lambda\right\rangle, \mathrm{t}_{\mathrm{m}}\right) \quad \lambda_{\mathrm{f}}=2.67 \times 10^{-2} \cdot \frac{\mathrm{W}}{\mathrm{m} \cdot{ }^{\circ} \mathrm{C}}
\end{aligned}
$$

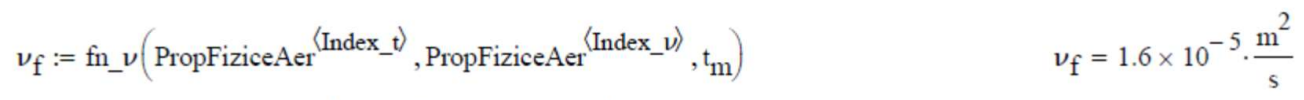

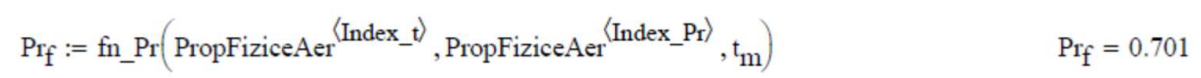

$$
\begin{aligned}
& \begin{array}{llll}
\text { Lungimea caracteristica } & 1_{\mathrm{c}}=\mathrm{d}_{\mathrm{e}} \quad 1_{\mathrm{c}}:=\mathrm{d}_{\mathrm{e}} \quad 1_{\mathrm{c}}=0.025 \mathrm{~m}
\end{array}
\end{aligned}
$$

Fig. 5. The calculus of mean temperature $t_{m}$ and thermophysical properties of the fluid (air)

The function for calculating the Gr number shall be introduced in accordance with relationship (3), where the volume expansion coefficient at constant pressure (isobaric volume expansion coefficient) $\beta$ is calculated using formula (16), approximating the behavior of fluid (air) with a perfect/ideal gas (GP/I)

$$
\beta \approx \frac{1}{T_{m}}\left[\frac{1}{\mathrm{~K}}\right]
$$

and $T_{m}$ represents the mean absolute temperature of the fluid.

For the determination of the fluid flow regime, using relationship (17) [1], [2], [3], [4], [6] etc. the value of product Gr·Pr or the Ra number shall be calculated (figure 6)

$$
R a=G r \cdot P r
$$




$$
\begin{aligned}
& \text { Criteriul Grashof } \mathrm{Gr}=\frac{\mathrm{g} \cdot \mathrm{l}_{\mathrm{c}}{ }^{3}}{v^{2}} \cdot \beta \cdot\left(\mathrm{t}_{1}-\mathrm{t}_{2}\right) \quad \mathrm{fn}_{2} \mathrm{Gr}\left(1_{\mathrm{c}}, \nu, \beta, \mathrm{t}_{1}, \mathrm{t}_{2}\right):=\frac{\mathrm{g} \cdot \mathrm{l}_{\mathrm{c}}{ }^{3}}{\nu^{2}} \cdot \beta \cdot\left|\left(\mathrm{t}_{1}-\mathrm{t}_{2}\right)\right|
\end{aligned}
$$

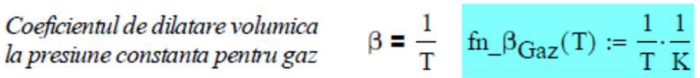

$$
\begin{aligned}
& \beta:=\mathrm{fn}_{-} \beta_{\mathrm{Gaz}}\left(\mathrm{t}_{\mathrm{m}}+273.15\right) \\
& \mathrm{Gr}:=\mathrm{fn}_{-} \mathrm{Gr}\left(1_{\mathrm{c}}, \nu_{\mathrm{f}}, \beta, \mathrm{t}_{\mathrm{se}}, \mathrm{t}_{\mathrm{f}}\right) \\
& \beta=3.2987 \times 10^{-3} \cdot \frac{1}{\mathrm{~K}} \\
& \mathrm{Gr}=7.89775 \times 10^{4} \\
& \text { Criterul Rayleigh (produsul Gr* } \mathrm{Pr} \text { ) } \quad \mathrm{Ra}_{\mathrm{f}}=\mathrm{Gr}_{\mathrm{f}} \cdot \mathrm{Pr}_{\mathrm{f}} \quad \mathrm{fn} \_\mathrm{Ra}(\mathrm{Gr}, \mathrm{Pr}):=\mathrm{Gr} \cdot \mathrm{Pr} \\
& \mathrm{Ra}:=\mathrm{fn} \_\mathrm{Ra}\left(\mathrm{Gr}, \mathrm{Pr}_{\mathrm{f}}\right) \\
& \mathrm{Ra}=5.53632 \times 10^{4}
\end{aligned}
$$

Fig. 6. The calculus of the Gr number and the product $\mathrm{Gr} \cdot \operatorname{Pr}($ the Ra number)

In solving the case of heat transfer by natural convection in open spaces, consideration was given to the use of an empirical correlation with general form (1), in which dimensionless constants $\mathrm{C}$ and $\mathrm{m}$ are chosen with respect to the fluid flow regime according to table 1 [1], [4], [5], [8], [9] etc.

Table 1

\section{C and $m$ constants characteristic to the empirical correlation (1) [1], [4], [5], [8], [9] etc.}

\begin{tabular}{|c|c|c|c|c|}
\hline $\begin{array}{c}\text { Crt } \\
\text { no. }\end{array}$ & Flow regime & Gr.Pr & $\mathrm{C}$ & $\mathrm{m}$ \\
\hline \hline 1 & Film & $10^{-4} \ldots 10^{-3}$ & 0.50 & 0 \\
\hline 2 & Transient & $10^{-3} \ldots .500$ & 1.18 & $1 / 8$ \\
\hline 3 & Laminar & $500 \ldots 2 \cdot 10^{7}$ & 0.54 & $1 / 4$ \\
\hline 4 & Turbulent & $2 \cdot 10^{7} \ldots 10^{13}$ & 0.135 & $1 / 3$ \\
\hline
\end{tabular}

The results obtained for the $\mathrm{Nu}$ number and the heat transfer coefficient by convection $\alpha_{\mathrm{C}}$ are shown in figure 7.

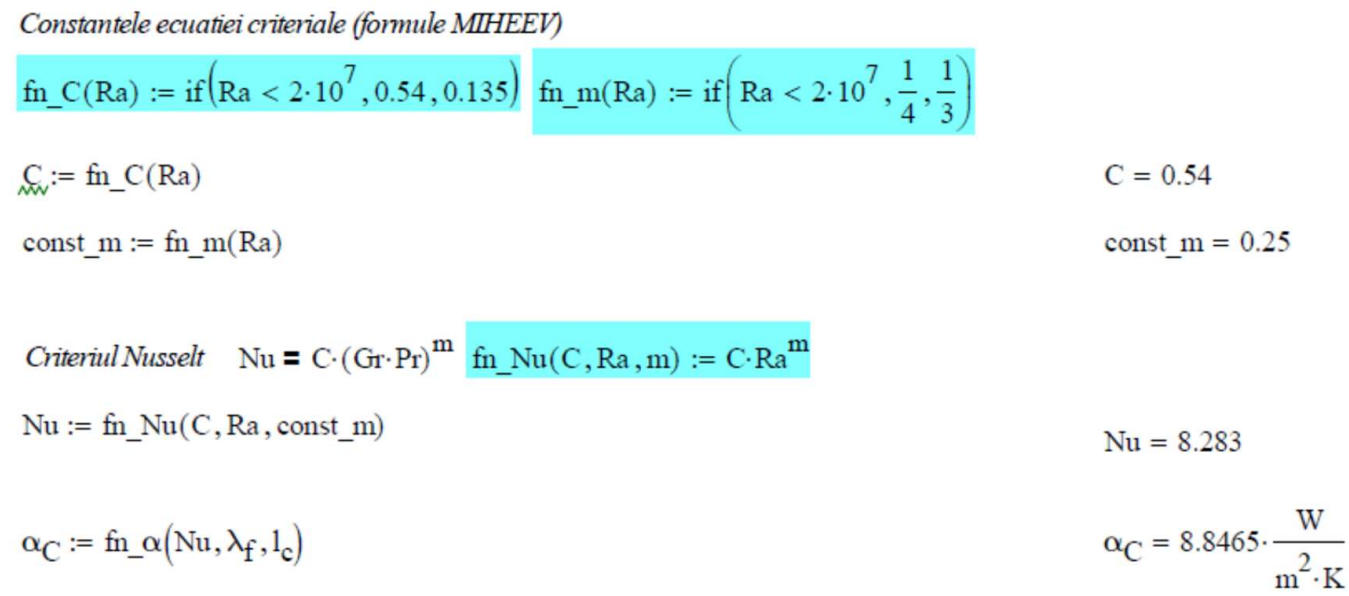

Fig. 7. The calculus of the Nu number and the heat transfer coefficient by convection $\alpha_{C}$ 
Steady heat transfer by natural (free) convection and radiation, for a horizontal circular pipe surrounded by air, using the Mathcad $($ software

To verify the final results obtained and also to calculate in other situations directly the heat transfer coefficient by convection $\alpha_{C}$, including for other fluids e.g., liquids the synthetic calculation function shown in figure 8 have been created.

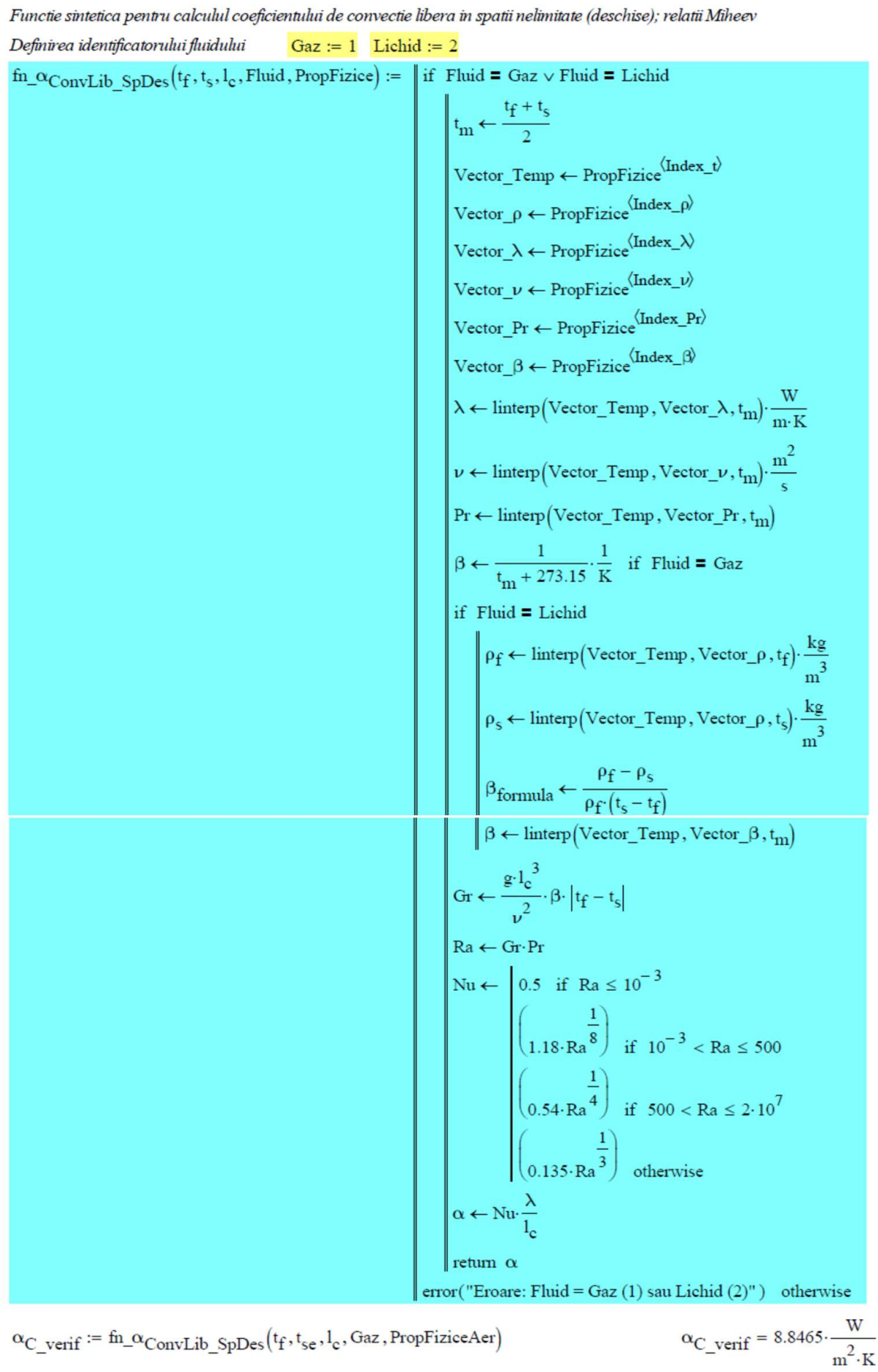

Fig. 8. Synthetic function for direct calculus of the heat transfer coefficient by convection $\alpha_{C}$ 
The calculus of the heat flux density $\dot{\mathrm{q}}_{\mathrm{C}}$ (per unit length), transferred by natural convection, was performed by implementing the relationship (7) and the value from figure 9 was obtained.

$$
\begin{aligned}
& \text { b) Fhxul termic transferat prin convectie de la corp la fluid }
\end{aligned}
$$

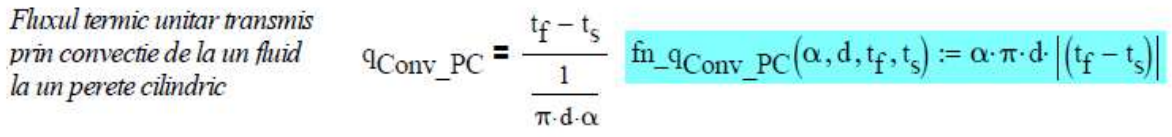

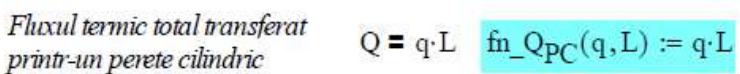

$$
\begin{aligned}
& \mathrm{q}_{\text {conv }}:=\mathrm{fn}_{-} \mathrm{q}_{\text {Conv_PC }}\left(\alpha_{\mathrm{C}}, \mathrm{d}_{\mathrm{e}}, \mathrm{t}_{\mathrm{f}}, \mathrm{t}_{\mathrm{se}}\right) \\
& \mathrm{q}_{\text {conv }}=27.792 \cdot \frac{\mathrm{W}}{\mathrm{m}} \\
& \mathrm{Q}_{\text {conv }}:=\mathrm{fn}_{-} \mathrm{Q}_{\mathrm{PC}}\left(\mathrm{q}_{\text {conv }}, \mathrm{L}\right) \\
& \mathrm{Q}_{\text {conv }}=27.792 \cdot \mathrm{W}
\end{aligned}
$$

Fig. 9. The calculus of the heat flux density $\dot{\mathrm{q}}_{\mathrm{C}}$ (per unit length)

To obtain the heat transfer coefficient by radiation $\alpha_{\mathrm{R}}$, the reciprocal emissionabsorption coefficient $\varepsilon_{12}$ (figure 10) has been calculated beforehand using the formula (9), in which the surface $S_{2}$ of the environment has been considered infinite $\left(S_{2}=\infty\right)$.

$$
\begin{aligned}
& \text { c) Coeficientul de TRQ superficial prin radiatie } \quad \alpha_{R} \\
& \text { Coeficientul reciproc de emisie } \\
& \text { pentru } 2 \text { suprafete cuprinse una in } \\
& \text { cealalta } S_{1}<S_{2} \\
& \varepsilon_{12 \_\mathrm{S} 1 \mathrm{~S} 2}=\frac{1}{\frac{1}{\varepsilon_{1}}+\frac{\mathrm{S}_{1}}{\mathrm{~S}_{2}} \cdot\left(\frac{1}{\varepsilon_{2}}-1\right)} \\
& \mathrm{fn}_{-} \varepsilon_{12} \mathrm{~S}_{1} \mathrm{~S}_{2}\left(\varepsilon_{1}, \varepsilon_{2}, \mathrm{~S}_{1}, \mathrm{~S}_{2}\right):=\frac{1}{\frac{1}{\varepsilon_{1}}+\frac{\mathrm{S}_{1}}{\mathrm{~S}_{2}} \cdot\left(\frac{1}{\varepsilon_{2}}-1\right)} \\
& \text { Arie laterala corp } \quad \mathrm{S}_{1}:=\pi \cdot \mathrm{d}_{\mathrm{e}} \cdot \mathrm{L} \\
& \mathrm{S}_{1}=0.079 \mathrm{~m}^{2} \\
& \text { Suprafata mediu ambiant (infinita) } \quad \mathrm{S}_{2}:=\infty \cdot \mathrm{m}^{2} \\
& \varepsilon_{12 \_\mathrm{S} 1 \mathrm{~S} 2}:=\mathrm{fn} \_\varepsilon_{12 \_\mathrm{S} 1 \mathrm{~S} 2}\left(\varepsilon_{\mathrm{s} 1}, \varepsilon_{\mathrm{s} 2}, \mathrm{~S}_{1}, \mathrm{~S}_{2}\right) \\
& \varepsilon_{12 \_ \text {S } 1 \mathrm{~S} 2}=0.8
\end{aligned}
$$

Fig. 10. The calculus of the reciprocal emission-absorption coefficient $\varepsilon_{12}$

The heat transfer coefficient by radiation $\alpha_{\mathrm{R}}$ (figure 11) was determined using the relationship (8), in which the absolute temperatures $\mathrm{T}_{\mathrm{s}}$ (surface temperature) and $\mathrm{T}_{\mathrm{e}}$ (outer fluid temperature), expressed in Kelvin degrees, were determined using the common transformation formula

$$
T[K]=t\left[{ }^{\circ} \mathrm{C}\right]+273.15
$$

which was implemented in the form of the function $f_{-} \mathrm{T}(\mathrm{t})$. 
Steady heat transfer by natural (free) convection and radiation, for a horizontal circular pipe surrounded by air, using the Mathcad® software

$$
\begin{aligned}
& \text { Coeficientul de transfer de caldura superficial prin radiatie } \\
& \alpha_{R}=\frac{\varepsilon_{p f} \cdot C_{0} \cdot\left[\left(\frac{T_{s}}{100}\right)^{4}-\left(\frac{T_{f}}{100}\right)^{4}\right]}{T_{s}-T_{f}} \quad f_{-} \alpha_{R}\left(\varepsilon_{p f}, C_{0}, T_{s}, T_{f}\right):=\frac{\varepsilon_{p f} \cdot C_{0} \cdot\left[\left(\frac{T_{s}}{100}\right)^{4}-\left(\frac{T_{f}}{100}\right)^{4}\right]}{T_{s}-T_{f}} \\
& \text { Temperatura absoluta } \quad \mathrm{T}=\mathrm{t}+273.15 \cdot \mathrm{K} \quad \text { fn_ } \mathrm{T}(\mathrm{t}):=(\mathrm{t}+273.15) \cdot \mathrm{K} \\
& \mathrm{T}_{\mathrm{S}}:=\mathrm{fn}_{-} \mathrm{T}\left(\mathrm{t}_{\mathrm{se}}\right) \quad \mathrm{T}_{\mathrm{e}}:=\mathrm{fn} \_\mathrm{T}\left(\mathrm{t}_{\mathrm{f}}\right) \quad \mathrm{T}_{\mathrm{s}}=323.15 \cdot \mathrm{K} \quad \mathrm{T}_{\mathrm{e}}=283.15 \cdot \mathrm{K} \\
& \alpha_{R}:=f_{-} \alpha_{R}\left(\varepsilon_{12} \mathrm{~S}_{1} \mathrm{~S} 2, \mathrm{C}_{0}, \mathrm{~T}_{\mathrm{S}}, \mathrm{T}_{\mathrm{e}}\right) \quad \quad \alpha_{\mathrm{R}}=5.077 \cdot \frac{\mathrm{W}}{\mathrm{m}^{2} \cdot \mathrm{K}}
\end{aligned}
$$

Fig. 11. The calculus of the heat transfer coefficient by radiation $\alpha_{R}$

The heat flux density $\dot{\mathrm{q}}_{\mathrm{R}}$ (per unit length), transferred by thermal radiation, was calculated using the relationship (10) and the results shown in figure 12 were obtained. For its verification, one can use as an alternative calculation the formula (19)

$$
\dot{q}_{R}=\varepsilon_{12} \cdot \sigma \cdot S_{1 u} \cdot\left(T_{1}{ }^{4}-T_{2}{ }^{4}\right)\left[\frac{\mathrm{W}}{\mathrm{m}}\right]
$$

where $\sigma$ represents the Stefan-Boltzmann constant $\sigma=5.67 \cdot 10^{-8} \frac{\mathrm{W}}{\mathrm{m}^{2} \cdot \mathrm{K}^{4}}$, and $\mathrm{S}_{1 \mathrm{u}}$ denotes the heat transfer lateral surface area per unit length $\left(S_{1 u}=\pi \cdot d_{e}\right)$.

d) Fhxul termic transmis prin radiatie

Fhxul termic unitar transmis prin radiatie intre 2 suprafete cilindrice

$$
\begin{array}{lr}
\mathrm{q}_{\mathrm{R}}=\varepsilon_{12} \cdot \mathrm{C}_{0} \cdot\left[\left(\frac{\mathrm{T}_{1}}{100}\right)^{4}-\left(\frac{\mathrm{T}_{2}}{100}\right)^{4}\right] \cdot \pi \cdot \mathrm{d}_{1} \quad \mathrm{fn}_{-} \mathrm{q}_{\mathrm{R}} \mathrm{SC}\left(\varepsilon_{12}, \mathrm{C}_{0}, \mathrm{~T}_{1}, \mathrm{~T}_{2}, \mathrm{~d}\right):=\varepsilon_{12} \cdot \mathrm{C}_{0} \cdot\left|\left(\frac{\mathrm{T}_{1}}{100}\right)^{4}-\left(\frac{\mathrm{T}_{2}}{100}\right)^{4}\right| \cdot \pi \cdot \mathrm{d} \\
\mathrm{q}_{\mathrm{R}}:=\mathrm{fn} \mathrm{q}_{\mathrm{R} \_\mathrm{SC}}\left(\varepsilon_{12}{ }_{-} \mathrm{S} 1 \mathrm{~S} 2, \mathrm{C}_{0}, \mathrm{~T}_{\mathrm{S}}, \mathrm{T}_{\mathrm{e}}, \mathrm{d}_{\mathrm{e}}\right) & \mathrm{q}_{\mathrm{R}}=15 \cdot 949 \cdot \frac{\mathrm{W}}{\mathrm{m}} \\
\text { Fhuxul termic total transmis prin radiatie } \quad \mathrm{Q}_{\mathrm{R}}:=\mathrm{q}_{\mathrm{R}} \cdot \mathrm{L} & \mathrm{Q}_{\mathrm{R}}=15.949 \cdot \mathrm{W}
\end{array}
$$

Varian ta decalcul

$$
\begin{array}{ll}
\mathrm{q}_{\mathrm{R}}=\varepsilon_{12} \cdot \sigma \cdot \mathrm{S}_{1 \mathrm{u}} \cdot\left(\mathrm{T}_{1}{ }^{4}-\mathrm{T}_{2}{ }^{4}\right) \quad \mathrm{fn}_{-} \mathrm{q}_{\mathrm{R}}\left(\varepsilon_{12}, \sigma, \mathrm{S}_{1 \mathrm{u}}, \mathrm{T}_{1}, \mathrm{~T}_{2}\right):=\varepsilon_{12} \cdot \sigma \cdot \mathrm{S}_{1 \mathrm{u}}\left|\left(\mathrm{T}_{1}{ }^{4}-\mathrm{T}_{2}{ }^{4}\right)\right| & \mathrm{q} 2 \mathrm{R}=15 \cdot 949 \cdot \frac{\mathrm{W}}{\mathrm{m}} \\
\mathrm{q}_{\mathrm{R}}:=\mathrm{fn} 2 \mathrm{q}_{\mathrm{R}}\left(\varepsilon_{12} \mathrm{~S} 1 \mathrm{~S} 2, \sigma, \pi \cdot \mathrm{d}_{\mathrm{e}}, \mathrm{T}_{\mathrm{s}}, \mathrm{T}_{\mathrm{e}}\right) & \\
\mathrm{Q}_{\mathrm{R}}=\varepsilon_{12} \cdot \sigma \cdot \mathrm{S}_{1} \cdot\left(\mathrm{T}_{1}{ }^{4}-\mathrm{T}_{2}{ }^{4}\right) \quad \mathrm{fn}_{2} \mathrm{Q}_{\mathrm{R}}\left(\varepsilon_{12}, \sigma, \mathrm{S}_{1}, \mathrm{~T}_{1}, \mathrm{~T}_{2}\right):=\varepsilon_{12} \cdot \sigma \cdot \mathrm{S}_{1} \cdot\left|\left(\mathrm{T}_{1}{ }^{4}-\mathrm{T}_{2}{ }^{4}\right)\right| & \mathrm{Q} 2 \mathrm{R}=15 \cdot 949 \cdot \mathrm{W}
\end{array}
$$

Fig. 12. The calculus and verification of the heat flux density $\dot{\mathrm{q}}_{\mathrm{R}}$ transferred by thermal radiation

Considering the simultaneous action of the two modes of heat transfer by thermal convection and thermal radiation, the combined heat transfer coefficient by convection and radiation $\alpha_{C R}$ was calculated using the relationship (11), and then using the formula 
(12) the heat flux density $\dot{\mathrm{q}}_{\mathrm{CR}}$ (per unit length) transferred by convection and radiation shall be calculated (figure 13).

Having previously calculated the partial results for the two-heat flux density $\dot{\mathrm{q}}_{\mathrm{C}}$ and $\dot{\mathrm{q}}_{\mathrm{R}}$, the heat flux density $\dot{\mathrm{q}}_{\mathrm{CR}}$ is checked using the relationship (14).

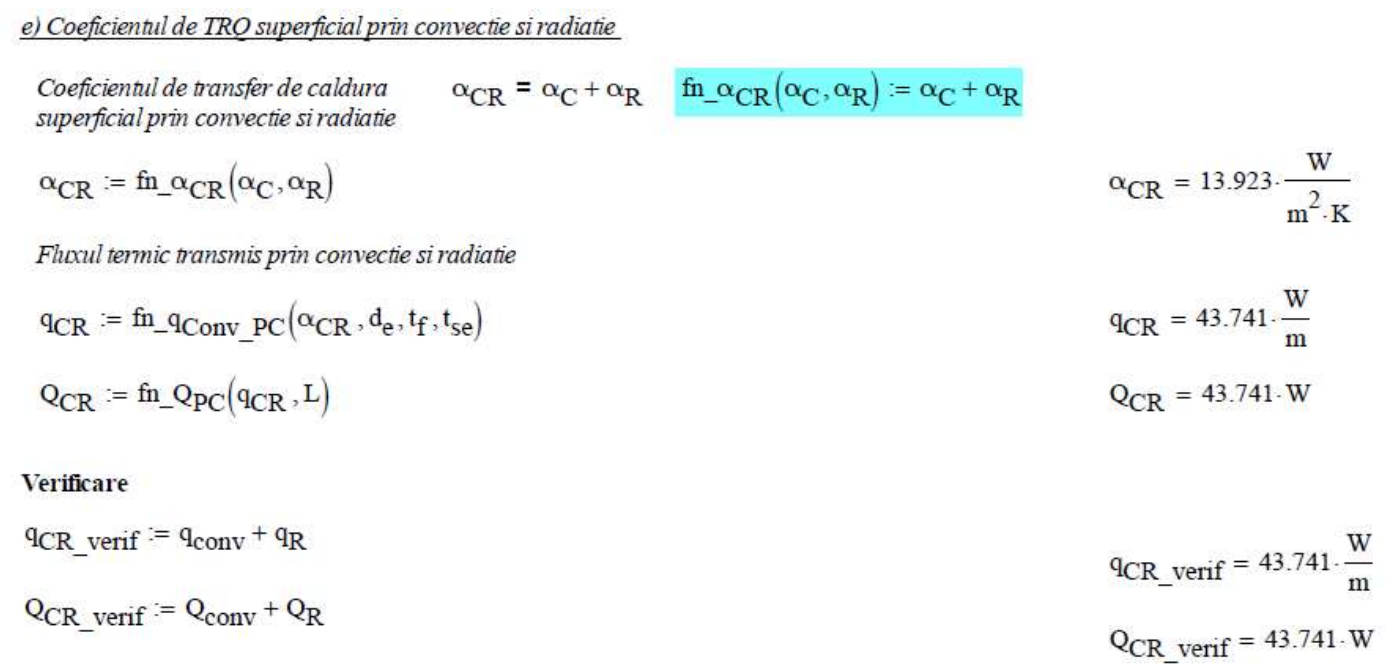

Fig. 13. The calculus of the combined heat transfer coefficient $\alpha_{C R}$ and heat flux density $\dot{q}_{C R}$ transferred by convection and radiation

For a comparative analysis and a better interpretation of the main results obtained, they have been summarized as shown in figure 14 .

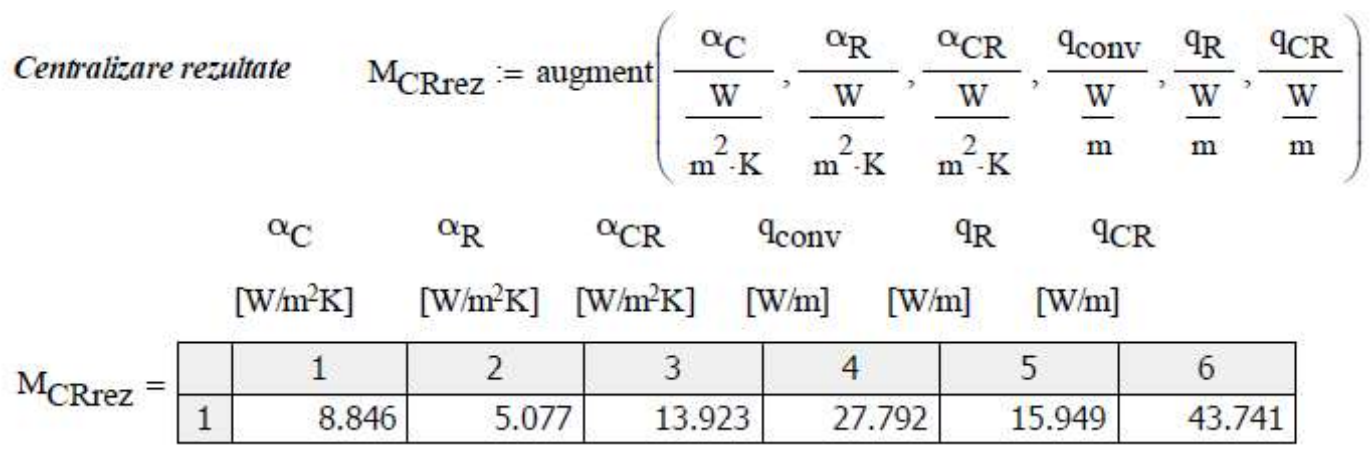

Fig. 14. Summary of the main results obtained for the coefficients $\alpha_{C}, \alpha_{R}, \alpha_{C R}$ and the heat flux densities $\dot{\mathrm{q}}_{\mathrm{C}}, \dot{\mathrm{q}}_{\mathrm{R}}$ and $\dot{\mathrm{q}}_{\mathrm{CR}}$

\section{Studied cases and results obtained}

Using the software tool shown above, the heat transfer problem proposed in the paper has been successfully solved, operating with a certain set of initial data.

Its usefulness is particularly proven in similar cases, where there are several changes in the application data compared to the reference situation under consideration, 
Steady heat transfer by natural (free) convection and radiation, for a horizontal circular pipe surrounded by air, using the Mathcad® software

for example the outer surface temperature of the pipe $t_{\text {se }}$ changes, the fluid temperature $t_{f}$ with which the heat exchange occurs changes, the outside diameter of the pipe or the pipe material changes etc.

The software tool presented has been used to analyze how the main results in figure 14 vary, for several cases where the outer surface temperature of the pipe $t_{\text {se }}$ changes within a range of technical interest, with values between $t_{\mathrm{se}}=40^{\circ} \mathrm{C} \ldots 90^{\circ} \mathrm{C}$, using a temperature step $\Delta \mathrm{t}_{\mathrm{se}}=5^{\circ} \mathrm{C}$.

The outside air temperature was considered to be constant, as in the proposed example, at $t_{\mathrm{f}}=10^{\circ} \mathrm{C}$ and the pipe geometry remained unchanged, the heat transfer being sought for the same steel pipe $\phi 1 "(25 \times 2.5 \mathrm{~mm})$.

The numeric results from the study were processed using the Microsoft Excel $\mathbb{}$ software and are summarized in figure 15.

\begin{tabular}{|c|c|c|c|c|c|c|c|c|}
\hline & $\begin{array}{l}\text { te } \\
{[C]}\end{array}$ & $\begin{array}{l}\text { tse } \\
{[C]}\end{array}$ & $\begin{array}{r}\text { Alfa_conv } \\
{[\mathrm{W} / \mathrm{mpK}]}\end{array}$ & $\begin{array}{l}\text { Alfa_rad } \\
{[\mathrm{W} / \mathrm{mpK}]}\end{array}$ & $\begin{array}{c}\text { Alfa_conv_rad } \\
{[\mathrm{W} / \mathrm{mpK}]}\end{array}$ & $\begin{array}{l}\text { q_conv } \\
{[W / m]}\end{array}$ & $\begin{array}{l}\text { q_rad } \\
{[\mathrm{W} / \mathrm{m}]}\end{array}$ & $\begin{array}{c}\text { q_conv_rad } \\
{[\mathrm{W} / \mathrm{m}]}\end{array}$ \\
\hline & 10.0 & 40.0 & 8.268 & 4.821 & 13.089 & 19.482 & 11.359 & 30.841 \\
\hline & 10.0 & 45.0 & 8.574 & 4.947 & 13.522 & 23.570 & 13.600 & 37.170 \\
\hline & 10.0 & 50.0 & 8.846 & 5.077 & 13.923 & 27.792 & 15.949 & 43.741 \\
\hline & 10.0 & 55.0 & 9.099 & 5.209 & 14.308 & 32.159 & 18.410 & 50.569 \\
\hline & 10.0 & 60.0 & 9.331 & 5.344 & 14.675 & 36.641 & 20.986 & 57.627 \\
\hline & 10.0 & 65.0 & 9.544 & 5.482 & 15.026 & 41.228 & 23.680 & 64.909 \\
\hline & 10.0 & 70.0 & 9.743 & 5.623 & 15.366 & 45.914 & 26.497 & 72.411 \\
\hline & 10.0 & 75.0 & 9.910 & 5.767 & 15.677 & 50.593 & 29.440 & 80.033 \\
\hline & 10.0 & 80.0 & 10.066 & 5.914 & 15.980 & 55.342 & 32.512 & 87.854 \\
\hline & 10.0 & 85.0 & 10.212 & 6.064 & 16.276 & 60.156 & 35.717 & 95.873 \\
\hline & 10.0 & 90.0 & 10.350 & 6.217 & 16.566 & 65.029 & 39.060 & 104.089 \\
\hline Media & 10.000 & 65.000 & 9.449 & 5.497 & 14.946 & 41.628 & 24.292 & 65.920 \\
\hline Variatie & & $125.000 \%$ & $25.18 \%$ & $28.96 \%$ & $26.56 \%$ & $233.790 \%$ & $243.868 \%$ & $237.502 \%$ \\
\hline
\end{tabular}

Fig. 15. The numeric results for the coefficients $\alpha_{C}, \alpha_{R}, \alpha_{C R}$ and the heat fluxes density $\dot{\mathrm{q}}_{\mathrm{C}}, \dot{\mathrm{q}}_{\mathrm{R}}$ and $\dot{\mathrm{q}}_{\mathrm{CR}}$ for a variation of the temperature $\mathrm{t}_{\mathrm{se}}$ in the range $\left[40^{\circ} \mathrm{C} \ldots 90^{\circ} \mathrm{C}\right]$

It is noted that, at a change of $125 \%$ in the outer surface temperature of the pipe $t_{\text {se }}\left(\right.$ from $t_{s e}=40^{\circ} \mathrm{C}$ to $t_{s e}=90^{\circ} \mathrm{C}$ ), the value of the coefficient $\alpha_{\mathrm{C}}$ is changed by about $25 \%$, the value of the coefficient $\alpha_{R}$ by about $29 \%$, resulting in a variation of the combined heat transfer coefficient by convection and radiation $\alpha_{\mathrm{CR}}$ of about $26.5 \%$.

Also, for the same temperature variation range of $t_{\text {se, }}$, there are significant increases in the heat fluxes density $\dot{\mathrm{q}}_{\mathrm{C}}, \dot{\mathrm{q}}_{\mathrm{R}}$ and $\dot{\mathrm{q}}_{\mathrm{CR}}$, their variations are about $234 \%$, $244 \%$ and $237.5 \%$ respectively.

The graphical representation of the variation of the coefficients $\alpha_{C}, \alpha_{R}$ and $\alpha_{C R}$ with temperature $t_{\mathrm{se}}$ is given in figures 16,17 and 18 , and the variation of the heat fluxes density $\dot{\mathrm{q}}_{\mathrm{C}}, \dot{\mathrm{q}}_{\mathrm{R}}$ and $\dot{\mathrm{q}}_{\mathrm{CR}}$ with temperature $\mathrm{t}_{\mathrm{se}}$ is shown graphically in figures 19,20 and 21 . 
Gelu-Adrian CHISĂLIŢĂ, Raluca MOLDOVAN

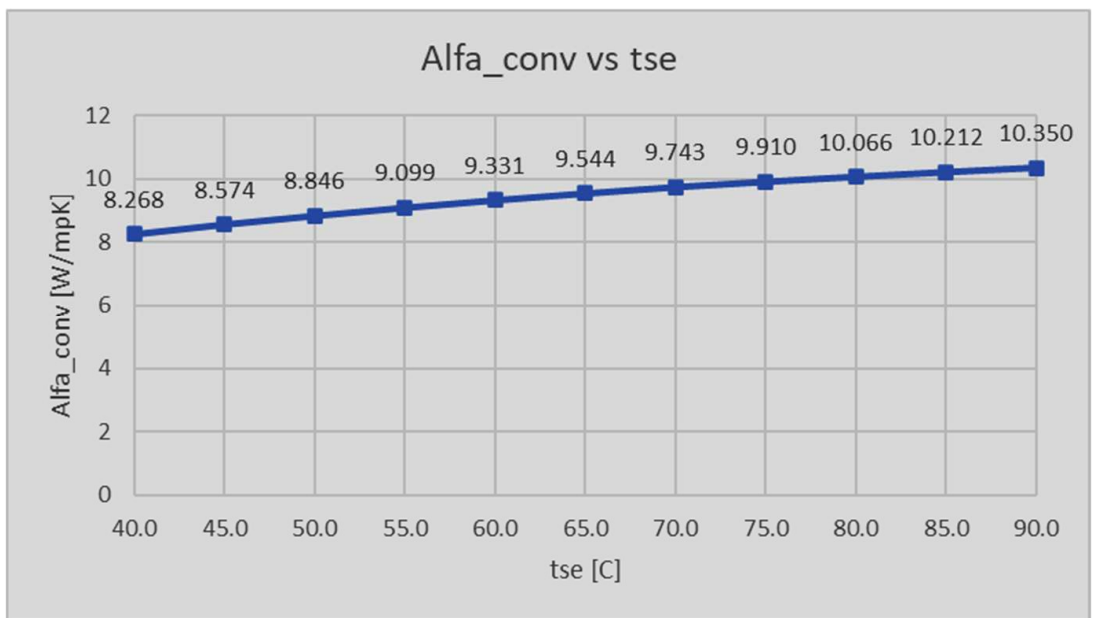

Fig. 16. The variation of coefficient $\alpha_{C}$ with temperature $t_{\text {se }}$

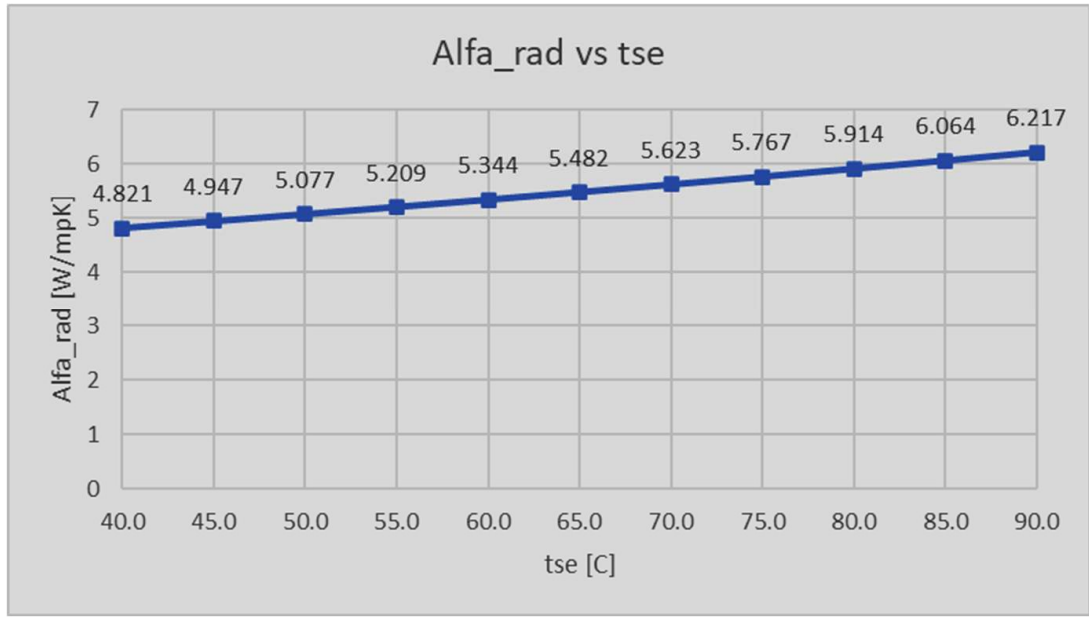

Fig. 17. The variation of coefficient $\alpha_{R}$ with temperature $t_{s e}$

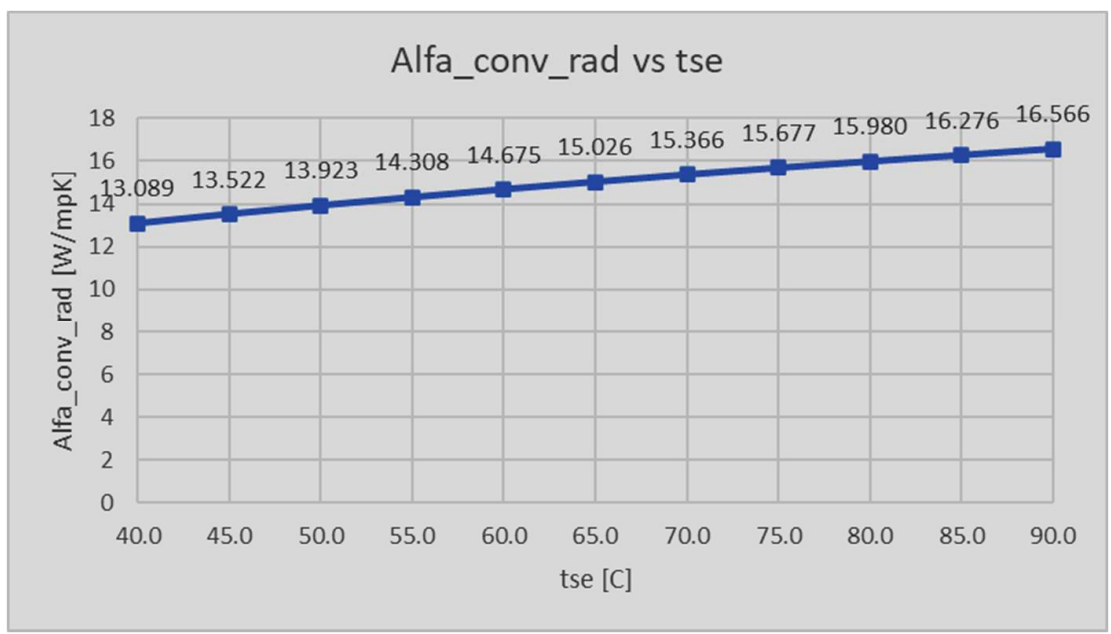

Fig. 18. The variation of coefficient $\alpha_{\mathrm{CR}}$ with temperature $t_{\mathrm{se}}$ 
Steady heat transfer by natural (free) convection and radiation, for a horizontal circular pipe surrounded by air, using the Mathcad ${ }^{\circledR}$ software

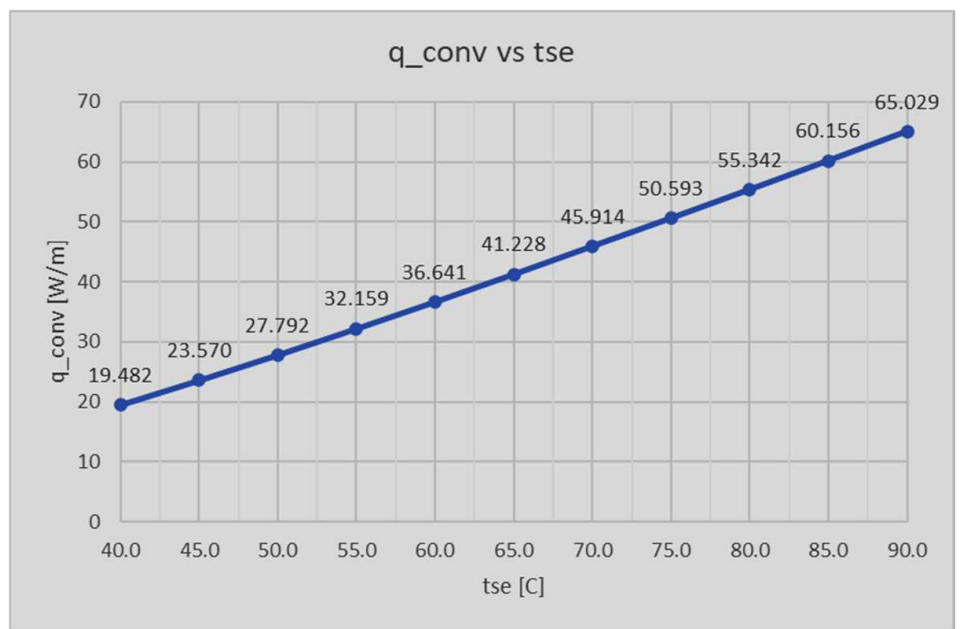

Fig. 19. The variation of heat flux density $\dot{\mathrm{q}}_{\mathrm{C}}$ with temperature $\mathrm{t}_{\mathrm{se}}$

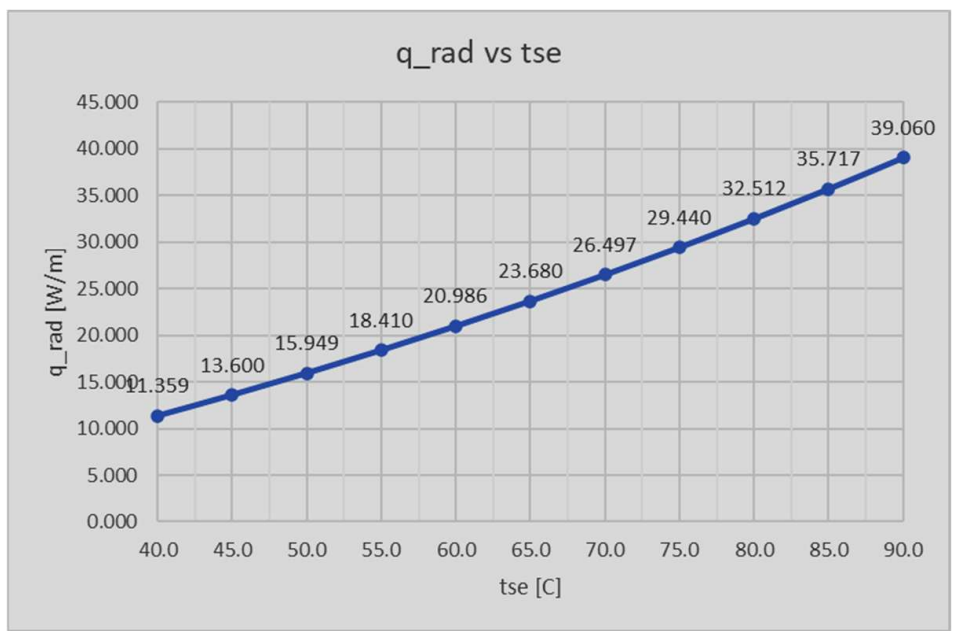

Fig. 20. The variation of heat flux density $\dot{\mathrm{q}}_{\mathrm{R}}$ with temperature $\mathrm{t}_{\mathrm{se}}$

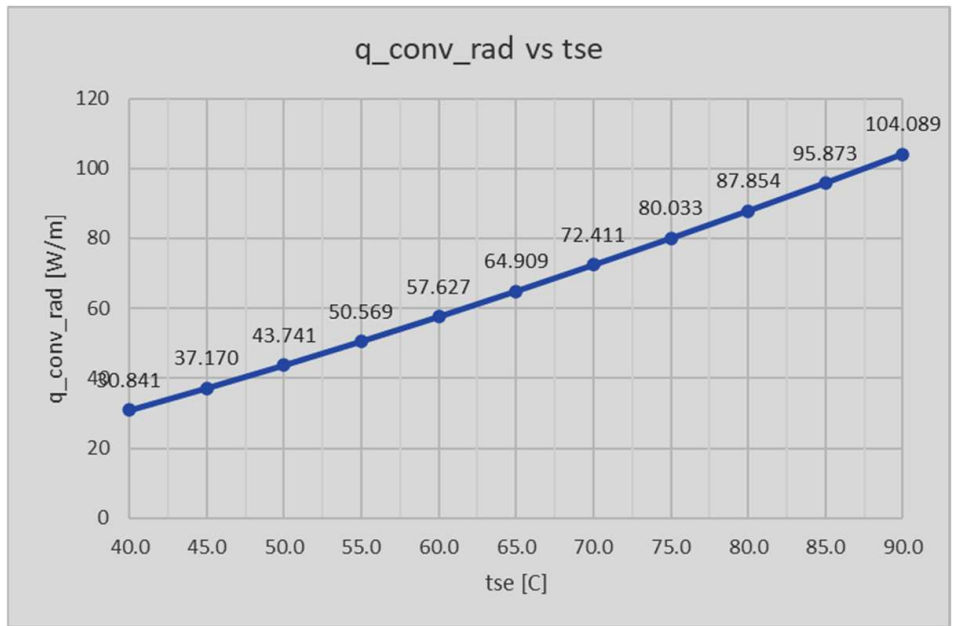

Fig. 21. The variation of heat flux density $\dot{\mathrm{q}}_{\mathrm{CR}}$ with temperature $\mathrm{t}_{\mathrm{se}}$ 
At the same time, the contribution of natural thermal convection and thermal radiation, to the combined transmission of heat through the two fundamental modes has been studied.

The numeric results are shown in figure 22 and their graphical representation in figure 23 (comparative) and figure 24 (combined).

\begin{tabular}{|c|c|c|c|c|}
\hline & $\begin{array}{l}\text { te } \\
\text { [C] }\end{array}$ & $\begin{array}{l}\text { tse } \\
{[C]}\end{array}$ & $\begin{array}{c}\text { q_conv } \\
\text { din } \\
\text { q_conv_rad } \\
{[\%]}\end{array}$ & $\begin{array}{c}\text { q_rad } \\
\text { din } \\
\text { q_conv_rad } \\
{[\%]}\end{array}$ \\
\hline & 10.0 & 40.0 & $63.169 \%$ & $36.831 \%$ \\
\hline & 10.0 & 45.0 & $63.411 \%$ & $36.589 \%$ \\
\hline & 10.0 & 50.0 & $63.538 \%$ & $36.462 \%$ \\
\hline & 10.0 & 55.0 & $63.594 \%$ & $36.406 \%$ \\
\hline & 10.0 & 60.0 & $63.583 \%$ & $36.417 \%$ \\
\hline & 10.0 & 65.0 & $63.517 \%$ & $36.482 \%$ \\
\hline & 10.0 & 70.0 & $63.407 \%$ & $36.593 \%$ \\
\hline & 10.0 & 75.0 & $63.215 \%$ & $36.785 \%$ \\
\hline & 10.0 & 80.0 & $62.993 \%$ & $37.007 \%$ \\
\hline & 10.0 & 85.0 & $62.746 \%$ & $37.254 \%$ \\
\hline & 10.0 & 90.0 & $62.474 \%$ & $37.526 \%$ \\
\hline Media & 10.000 & 65.000 & $63.241 \%$ & $36.759 \%$ \\
\hline Variatie & & & $-1.100 \%$ & $1.886 \%$ \\
\hline
\end{tabular}

Fig. 22. The share of natural thermal convection and thermal radiation in the transmission of heat flux density $\dot{\mathrm{q}}_{\mathrm{CR}}$, for different values of temperature $\mathrm{t}_{\mathrm{se}}$

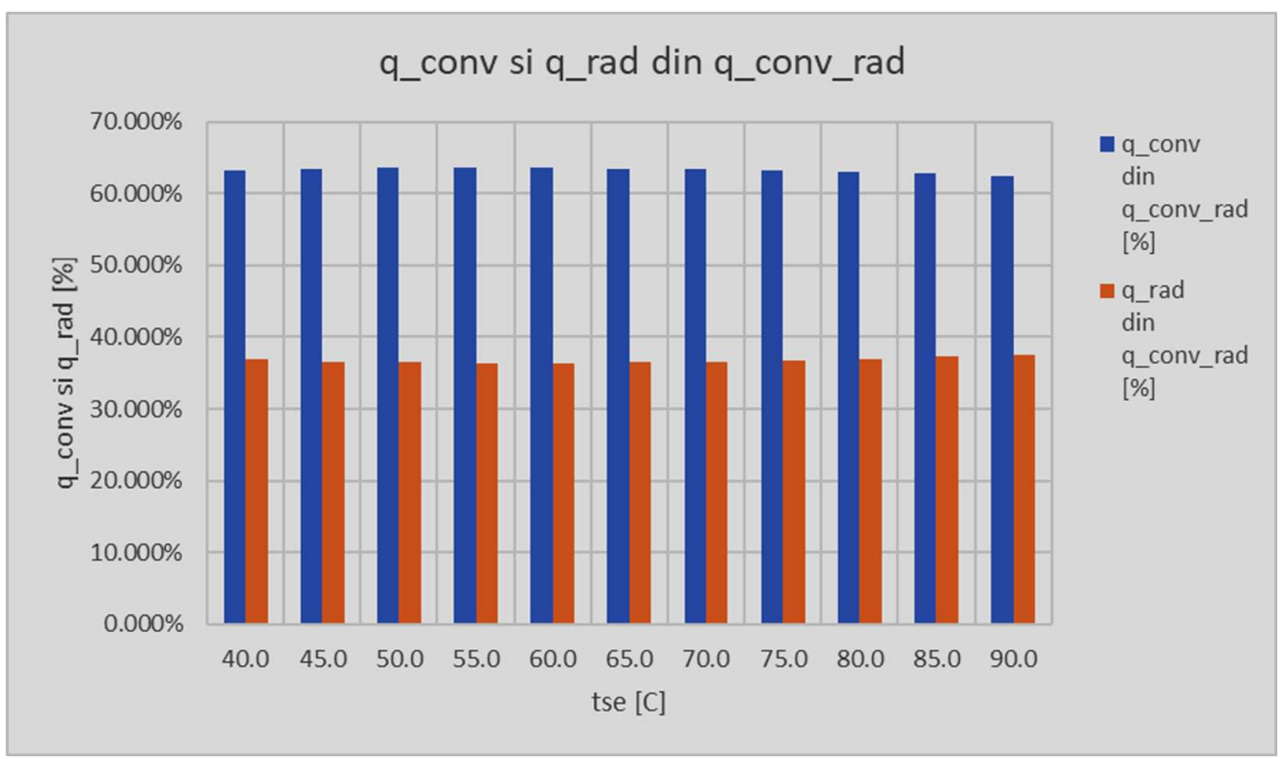

Fig. 23. The share of natural thermal convection and thermal radiation in the transmission of heat flux density $\dot{\mathrm{q}}_{\mathrm{CR}}$ (comparative representation) 
Steady heat transfer by natural (free) convection and radiation, for a horizontal circular pipe surrounded by air, using the Mathcad ${ }^{\circledR}$ software

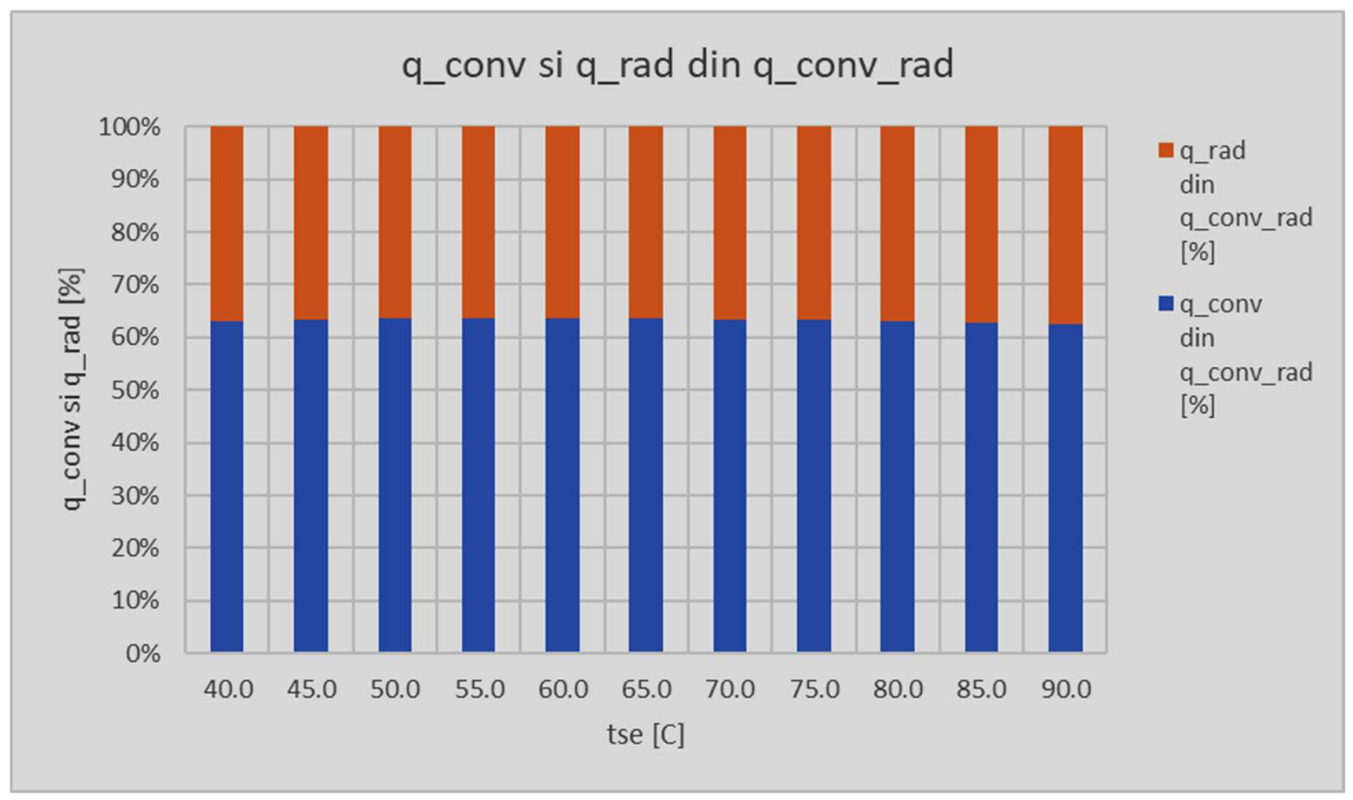

Fig. 24. The share of natural thermal convection and thermal radiation in the transmission of heat flux density $\dot{\mathrm{q}}_{\mathrm{CR}}$ (combined representation)

It is noted that in the temperature range studied $\mathrm{t}_{\mathrm{se}}=40^{\circ} \mathrm{C} \ldots 90^{\circ} \mathrm{C}$, the natural thermal convection accounts for about $62-63 \%$ and the remaining $38-37 \%$ is the transmission of heat by thermal radiation.

It has also been noted that for values of temperature $t_{s e}$ higher than $55-60^{\circ} \mathrm{C}$, the contribution of natural thermal convection has a slight decrease from $63.59 \%$ to $62.47 \%$ and thermal radiation has slightly increased from $36.4 \%$ to $37.52 \%$ of the total transferred heat flux density $\dot{\mathrm{q}}_{\mathrm{CR}}$.

With lower values of the outer surface temperature of the pipe, usually below $100^{\circ} \mathrm{C}$, there is generally a tendency to neglect the effect of thermal radiation by considering it less important and the calculation of the transferred heat flux density $\dot{q}$ is based mainly on the treatment of the phenomenon of natural thermal convection $(\dot{\mathrm{q}} \approx$ $\left.\dot{\mathrm{q}}_{\mathrm{C}}\right)$.

Considering the above results, neglecting the effect of thermal radiation, even in the case of values of temperature $t_{\mathrm{se}}$ within the usual technical range of $40^{\circ} \mathrm{C} \ldots 90^{\circ} \mathrm{C}$, may lead primarily to a relatively erroneous assessment of the value of the heat transfer coefficient $\alpha$, and then, to the estimation with a high technical error of about $37 \%$ (figure 22) of the transferred heat flux density $\dot{\mathrm{q}}$, which actually represents the heat loss to the environment. 


\section{Conclusions}

The solution of an application of steady heat transfer by natural (free) convection and thermal radiation is generally a slightly more complex one, which requires treatment of both fundamental modes of heat transfer and then combining the results to obtain the final values of the heat transfer coefficient and the heat flux density or total heat flux transferred.

Implementation of the solution to the proposed problem and the development of the study presented in the paper have been carried out using the MathCAD ${ }^{\circledR}$ software application, taking into account the benefits of this computer program in terms of describing calculation relationships in a language close to the natural one, ability to operate with different measurement units, creation of functions used in calculations, management of fluid thermophysical properties, presentation of obtained numerical and/or graphical results etc.

Preparation to solve the studied case was made by entering the initial data of the problem represented by working fluid characteristics, geometrical and thermal characteristics of the pipe, emission-absorption coefficients of the body and the environment, the value of the radiation coefficient of the absolute black body and the Stefan-Boltzmann constant (figure 2).

The approach to heat transmission by natural convection was carried out using appropriate empirical correlations specified in the literature having the general form (1), in which the Grashof (Gr) and the Prandtl (Pr) numbers are calculated with the established relationships (3) and (4).

The determination of the thermophysical properties of the working fluid shall be carried out using the reference temperature indicated in the empirical correlation tables, the tabular values for fluid properties and the use of required linear interpolation functions (figure 3 and figure 4). The determination of the fluid flow regime is made by calculating the value of product $\mathrm{Gr} \cdot \operatorname{Pr}$ or the Ra number (figure 6), then identifying the $\mathrm{C}$ and $\mathrm{m}$ constants of the empirical correlation. One will compute the value of Nusselt number $(\mathrm{Nu})$ and using the relationship (5) the heat transfer coefficient by natural convection $\alpha_{\mathrm{C}}$ is obtained (figure 7). A synthetic calculation function shown in figure 8 was created to verify the result obtained and/or to calculate in other situations directly the heat transfer coefficient by natural convection.

The heat flux density $\dot{\mathrm{q}}_{\mathrm{C}}$ (per unit of length), transferred by natural convection, was calculated by the implementation of the relationship (7) and the results were displayed in figure 9.

The approach to heat transmission by thermal radiation is carried out by determining the heat transfer coefficient by radiation $\alpha_{R}$ (figure 11) using the relationship (8), first calculating the reciprocal emission-absorption coefficient $\varepsilon_{12}$ with the relationship (9) and then using the relation (10) the heat flux density $\dot{\mathrm{q}}_{\mathrm{R}}$ (per unit of length) transferred by thermal radiation, which has the value shown in figure 12 . 
Steady heat transfer by natural (free) convection and radiation, for a horizontal circular pipe surrounded by air, using the Mathcad $\AA$ software

Considering the simultaneous action of the two modes of heat transfer by natural convection and thermal radiation, using the relationship (11) the combined heat transfer coefficient by convection and radiation $\alpha_{\mathrm{CR}}$ shall be calculated, and then using the formula (12) the heat flux density $\dot{\mathrm{q}}_{\mathrm{CR}}$ (per unit of length) transferred by convection and radiation shall be determined (figure 13).

Since partial results have been determined for the heat fluxes density $\dot{\mathrm{q}}_{\mathrm{C}}$ and $\dot{\mathrm{q}}_{\mathrm{R}}$, the resulting heat flux density $\dot{\mathrm{q}}_{\mathrm{CR}}$ can be verified by using the relationship (14).

Using the software tool presented in the paper, a number of cases have been investigated, where for the same steel pipe $\phi 1 "(25 \times 2.5 \mathrm{~mm})$ and a temperature of outside air of $t_{\mathrm{f}}=10^{\circ} \mathrm{C}$, the temperature of the outer surface of the pipe $t_{s e}$ changes in a range $t_{s e}=40^{\circ} \mathrm{C} \ldots 90^{\circ} \mathrm{C}$. A temperature step $\Delta t_{\mathrm{se}}=5^{\circ} \mathrm{C}$ has been selected to determine the following results:

- The heat transfer coefficient by convection $\alpha_{C}$;

- The heat transfer coefficient by radiation $\alpha_{R}$;

- The combined heat transfer coefficient by convection and radiation $\alpha_{\mathrm{CR}}$;

- The heat flux density transferred by natural convection $\dot{\mathrm{q}}_{\mathrm{C}}$;

- The heat flux density transferred by radiation $\dot{\mathrm{q}}_{\mathrm{R}}$;

- The heat flux density transferred by natural convection and radiation $\dot{\mathrm{q}}_{\mathrm{CR}}$.

The numeric results obtained are summarized in figure 15. The graphical representation of the variation of the coefficients $\alpha_{C}, \alpha_{R}$ and $\alpha_{C R}$ with temperature $t_{s e}$ is given in figures 16, 17 and 18, and the variation of the heat fluxes density $\dot{\mathrm{q}}_{C}, \dot{\mathrm{q}}_{\mathrm{R}}$ and $\dot{\mathrm{q}}_{\mathrm{CR}}$ with temperature $\mathrm{t}_{\mathrm{se}}$ is shown graphically in figures 19,20 and 21 .

From the results obtained it was noted that a change in the value of the outer surface temperature of the pipe $t_{\text {se }}$ by $125 \%$, from $40^{\circ} \mathrm{C}$ to $90^{\circ} \mathrm{C}$, corresponds to a change in the value of the $\alpha_{C}$ coefficient of about $25 \%$, the value of the $\alpha_{R}$ coefficient by about $29 \%$ and the value of the combined heat transfer coefficient by convection and radiation $\alpha_{\mathrm{CR}}$ by about $26.5 \%$.

The share of natural convection and thermal radiation in combined heat transfer through the two fundamental modes, was also analyzed. The numerical results are shown in figure 22 and their graphical representation has been shown comparative in figure 23 and combined in figure 24 .

It has been noted that in the temperature range studied $t_{\mathrm{se}}$, the natural convection accounts for approximately $62-63 \%$ and the remaining approximately $38-37 \%$ is the transmission of heat by thermal radiation. At the same time, it is noted that for values of temperature $\mathrm{t}_{\mathrm{se}}$ higher than $55-60^{\circ} \mathrm{C}$, the contribution of natural thermal convection has a slight decrease from $63.59 \%$ to $62.47 \%$ and thermal radiation has slightly increased from $36.4 \%$ to $37.52 \%$ of the total transferred heat flux density $\dot{\mathrm{q}}_{\mathrm{CR}}$.

Considering the results presented above, it is assessed that neglecting the heat transfer by radiation, even in the case of temperature $t_{\text {se }}$ within a technical range normally encountered in building services engineering $\left(40^{\circ} \mathrm{C} \ldots 90^{\circ} \mathrm{C}\right)$, may lead to a relatively erroneous assessment of the value of the heat transfer coefficient $\alpha$ (figure 15). 
In direct correlation with this, due to Newton's law (6), the determination with a high technical error of approximately $37 \%$ of the heat lux density $\dot{q}$ (figure 22) transferred to the external fluid will then be found, which represents for the cases studied in the paper the heat loss to the environment.

Considering the current context, where particular emphasis is placed on the most efficient use of energy, the use of clean alternative energy sources, the reduction of heat losses, the efficiency increases of thermal equipment and installations, the reduction of environmental pollution etc., the estimation of heat transfer as close as possible to reality in situations like those presented in the paper is becoming an increasingly important goal.

While taking into account the heat transfer by radiation at low temperatures also requires an additional calculation effort, being necessary to determine in addition other heat transfer quantities such as: the coefficient by radiation $\alpha_{\mathrm{R}}$, the combined heat transfer coefficient by convection and radiation $\alpha_{\mathrm{CR}}$, the heat flux density transferred by radiation

$\dot{\mathrm{q}}_{\mathrm{R}}$, the heat flux density transferred by convection and radiation $\dot{\mathrm{q}}_{\mathrm{CR}}$, the results of this more complex mathematical model better approximate the way in which the heat transfer is actually occurring, generating much more reliable results from a technical point of view.

The solution of the example proposed in the paper and the software tool developed for the analysis of the combined heat transfer by free convection and thermal radiation is useful both to students at the Faculties of Building Services Engineering, who study the heat transfer, as well as specialists in the field interested in the practical solution of these engineering applications.

\section{Bibliography}

[1] Chisăliţă, G.A., Transmiterea căldurii, Note de curs, 2010-2021.

[2] Bergman, T.L., Lavine, A.S., Incropera, F.P., Dewitt D.P., Fundamentals of Heat and Mass Transfer, 7th edition, ISBN 978-0470-50197-9, John Wiley \& Sons, Inc., 2011, pp. 594-616, 862-895.

[3] Cengel, Y.A., Ghajar A.J., Heat and Mass Transfer: Fundamentals and Applications, 5th edition, ISBN 978-0073398181, McGraw-Hill Education, 2014, pp. 459-473, 606-641.

[4] Leonăchescu, N., Termotehnică, E.D.P, Bucureşti, 1981, pp. 413-418, 458-467.

[5] Opriţoiu, A., Termotehnică şi aparate termice - Transmiterea căldurii, Litografia I.P.C.-N., ClujNapoca, 1992, pp. 111-121, 186-197.

[6] Lienhard IV, J.H., Lienhard V, J.H., A Heat Transfer Textbook, 4th edition, ISBN 0-486-47931-5, Dover Publications Inc., 2011, pp. 399-429, 538-565.

[7] Popa B., Vintilă C., Transfer de căldură în procese industriale, Editura Dacia,Cluj-Napoca, 1975, pp. 111-142, 257-280.

[8] Leonăchescu, N. ş.a., Probleme de termotehnică, E.D.P, Bucureşti, 1977, pp. 277-281, 439, 515-524.

[9] Muntea, C., Câmpeanu, A., Transfer de căldură - Probleme, ISBN 973-95386-2-2, Editura Ana, Cluj-Napoca, 1997, pp. 54-70, 89-95, 141, 194-195. 